\title{
Mala Bizta Sochal Klu: underground, alternative and commercial in Havana hip hop
}

\author{
GEOFF B A KER \\ Department of Music, Royal Holloway, University of London, Egham, Surrey TW20 OEX, UK \\ E-mail: geoff.baker@rhul.ac.uk
}

\begin{abstract}
The terms underground, alternative and commercial are widely used in discussions of popular music scenes in Havana and around the world. In Cuba, the words alternative and underground are often used interchangeably, in critical as well as popular discourse. I propose a working definition of, and a distinction between, these terms in Havana, since to render them synonymous reduces their usefulness. The distinction between underground and commercial, in contrast, is widely seen as self-evident, by critics as well as by fans. However, a simplistic dichotomy glosses over the interpenetration of these terms, which are of limited use as analytical categories. This discussion of terminology is grounded in an analysis of the politics of style in Havana hip hop.
\end{abstract}

\section{Introduction}

[it's] the dark side of Cuban music ... it's neither Compay [Segundo], with the greatest respect, nor the conga drum for the tourists. ... (Underground rap-metal artist Jorge Rafael López on his alias, Mala Bizta Sochal Klu)

We're all underground here. In this country, everything's underground. (Yrak Saenz of rap group Doble Filo)

The trailer for the documentary Cuba Rebelión: Underground Music in Havana begins: 'Since the nineties, an alternative music scene has come into existence in Cuba. An underground scene of young musicians who, despite their creative suppression and censorship, have the courage to make a statement.' I examine the questions of suppression and censorship elsewhere (Baker 2011b); here I want to focus on the slippage between the terms alternative and underground. This slippage is found not just in popular usage but also in critical and academic studies. Even the most authoritative work to date on Cuban alternative music, by Joaquín Borges-Triana (2009), makes no clear distinction between these terms, and the author's description of Habana Blues as 'a fictional filmed vision of the Havana underground scene' (Borges-Triana 2009, p. 10) ${ }^{1}$ illustrates this lack of clarity: the main musical protagonist is X Alfonso, a darling of the Havana cultural establishment and creator of several commercially released albums, who performs in Havana's most prestigious venues (he even starred in Juanes' huge 'Paz sin fronteras' concert in the Plaza de 
la Revolución in September 2009) and regularly tours overseas. If, as Borges-Triana (2009, p. 243) suggests, drawing on Roy Shuker, underground equates to noncommercial and inaccessible to non-members of a given scene, then $\mathrm{X}$ Alfonso clearly does not fit this bill, though few would dispute that he is a figurehead of Cuban alternative music. My first aim in this article is therefore to propose a working definition of, and a distinction between, underground and alternative with respect to Havana's music scenes (a distinction which may be relevant to other contexts); to render these terms synonymous reduces their usefulness.

Borges-Triana also brings up the oft-quoted dichotomy of underground and commercial. If the terms underground and alternative are often used interchangeably, the distinction between underground and commercial is widely seen as selfevident, and it is reinforced by many academic and critical interventions as well as in everyday conversations. However, a simplistic polarisation glosses over the interpenetration of these terms. As Sarah Thornton (1995) argues, such binary oppositions play an important part in the construction of identity, but academics have a duty to examine them critically because they are unlikely to be useful as analytical categories; in other words, they reflect distinctions at the level of identity rather than 'real' differences. In the case of underground and alternative, however, I will argue that there are indeed real differences between groups, in terms of musical aesthetics, geographical location, audience composition, and so on, and that these distinctions ought to be marked linguistically. I will thus seek to clarify the underground/alternative question but to complicate the underground/commercial one; in examining these discursive categories, I hope to shed light on debates over the politics of culture in 21st-century Havana. $^{2}$

\section{Underground or alternative?}

In her study of rock music in Hungary in the 1980s and 1990s, Anna Szemere associates underground culture with the socialist era and alternative music with postsocialism. She writes that the underground culture of the 1980s

emphasised recalcitrance toward the dominant (official) culture. The metaphor 'underground', widely used by the musicians as a self-reference, suggested a position underneath a more powerful and more visible entity. The political connotation of the term was obvious. 'Alternative', by contrast, refers to spaces that are horizontally rather than hierarchically structured. It implicates choice rather than the force or compulsion connoted by 'underground'. [...] The local underground of the 1980s formed a close-knit and cohesive social world, an art world with solid boundaries. The alternatives' social world in postcommunist Hungary, by contrast, is fragmented and its boundaries are porous. (Szemere 2001, p. 16)

Szemere's study treats underground and alternative as successive phases, something also noted by Laudan Nooshin (2005) in her study of Iranian rock music. In Havana, however, underground and alternative live side by side, perhaps reflecting the fact that the city is experiencing socialism and post-socialism simultaneously, or that its temporality is confused: as rappers Los Aldeanos put it, 'other countries have a future, we've already had ours, we're going backwards'. ${ }^{3}$ Nevertheless, Szemere's comments are highly pertinent to music in Havana; with reference to hip hop and fusion, I will argue that two broad groups of artists can be perceived and that 
Szemere's definitions can help to draw distinctions between them, justifying the use of the labels alternative and underground as meaning different things.

Artists such as X Alfonso, Telmary, Free Hole Negro and Kumar (all of whom appear or are heard in Habana Blues) are rappers or hip hop-influenced musicians who have a relatively smooth relationship with the Cuban state; as a result of their careful political positioning, they are able to live transnational existences, either touring extensively or basing themselves overseas, and thus their social and artistic world is, as Szemere suggests, 'fragmented and its boundaries are porous'. If 'alternative culture, unlike the underground [...], is more of a partner of the mainstream culture apparatus than the suppressed other', as Szemere (2001, p. 17) puts it - a view echoed by Nooshin (2005, pp. 475-6), who describes a shift in usage from the term underground to alternative as a strategy to play down oppositionality and gain official acceptance - then these artists fit the bill. X Alfonso and Robertico Carcassés, director of Interactivo, a fusion collective to which rappers Telmary and Kumar belong, are from families of musicians that have prospered under the Cuban Revolution; $X$ Alfonso is the son of Síntesis director Carlos Alfonso, while Carcassés's father Bobby is a legendary jazz musician and entertainer. Thanks to their families' harmonious relationship with the state, they are among the privileged stratum of Cuban musicians whose careers more closely resemble those of internationally active artists in other countries.

In contrast, artists such as Los Aldeanos, Mano Armada, Hermanos de Causa and other members of the collective La Comisión Depuradora ('the purifying commission') participate in a more cohesive hip hop scene, self-defined as underground and a community or movement. Szemere (2001, p. 45) notes that underground rockers in Hungary preferred to play live to a small, fanatical public, fostering 'a closeknit and cohesive social world'. With regard to US hip hop, Imani Perry (2004, pp. 202-3), too, argues that 'underground artists are those [...] who see as their primary frame of reference the hip hop community'. The underground is thus tied closely to live performance before and interaction with a relatively consistent public, immediacy of communication and notions of democratic participation. The aesthetic extremism of the rock and hip hop scenes, which provide little space for musical experimentation, further serves to keep most performances small and intimate, more like communal rituals of belonging and reaffirmation than opportunities to preach to the unconverted. The underground is a social space that fosters a particular set of behaviours that tend to reinforce a sense of exclusivity, whereas the aesthetics and behaviours associated with alternative music might be considered more inclusive (and thus less clearly defined).

The underground music scene is territorialised, rooted in specific urban sites, whereas the musicians whom I am defining as alternative are not; if Los Aldeanos are associated with particular Havana locales, above all the small club Barbarám in Nuevo Vedado, many alternative musicians live or tour overseas. Alternative music can be heard regularly in the mass media, whereas catching underground music usually requires attending a performance or copying digital music files. ${ }^{4}$ However, this does not mean that underground equates to hidden or inaccessible: pace Borges-Triana, in many cases it is easier to see underground artists perform live than (more famous) alternative ones, since the latter are often abroad and the peculiarities of Havana's music economy mean that it is not always viable for them to do regular concerts at home ( $X$ Alfonso being one well-known alternative musician whose concerts are something of a rarity). Furthermore, the digital 
revolution has further blurred this question of accessibility: the home-produced music of Los Aldeanos circulates far more widely than that of the state-sanctioned groups belonging to the Cuban Rap Agency. Going through official channels in Cuba, such as releasing an album on the rap agency label, Asere, can be a painfully slow process: Ogguere, for example, who chose to go down this route with their album Llena de Amor el Mambo, found their music 'hidden' for a long period as a result, and in the meantime Los Aldeanos produced several demos that circulated freely in digital form. Thanks to digital technology, rappers Los Aldeanos and reguetonero ('reggaetón artist') Elvis Manuel have been some of the most audible urban musicians in Havana in recent years, despite being, in many senses of the word, underground.

With regard to musical style, underground may be conceived of in terms of close affiliation to specific international musical genres and scenes, whereas alternative may usefully refer to a more eclectic, pick ' $n$ ' mix approach. In different genres, underground refers to a different such connection: in the case of hip hop, with New York-style message rap; in reggaetón, with perreo or Puerto Rican beats (indeed, 'underground' was an early name for Puerto Rican reggaetón in the 1990s); and in rock, with Anglo-American punk and heavy metal. Underground generally entails a rejection of musical localisation or adaptation ('Cubanisation') and a preference for unadulterated foreign styles. In 2007, underground reguetoneros Elvis Manuel and El Micha's instrumentals were heavily influenced by Puerto Rican models and particularly favoured the distinctive upward semitone shift made famous by Daddy Yankee's 'Gasolina'. The characteristic beats of underground rap since 2004 have been those of Papá Humbertico, Aldo Rodríguez (Los Aldeanos), Randee Akozta and Lápiz: hard-edged and dark, rarely with any surface Cuban musical features, and frequently based on samples of European classical music, Spanish pop, or film music. These producers regard Cubanised fusion with scepticism. Underground rock, meanwhile, is dominated by heavy, black and death metal tendencies, and is often sung in English. It is notable that Qva Libre, the only group in Cuba Rebelión that mixes rock with traditional Cuban music, describe themselves as alternative musicians in the film. Underground musicians thus derive their authenticity from connection to the core values of a musical genre whose true home is perceived as being overseas.

Alternative music is more stylistically experimental and eclectic, mixing hip hop with elements of jazz, funk, rock and reggae, and in dialogue with Cuban traditions like rumba, son, mambo and timba. Key alternative music albums by artists such as X Alfonso (Revoluxion), Telmary (A Diario), Free Hole Negro (Superfinos Negros) and Ogguere (Llena de Amor el Mambo) are distinguished by their stylistic variety. Interestingly, a number of rappers who moved towards a more 'localised' (or alternative) sound did so as a result of exposure (or desire for exposure) to overseas audiences; in contrast, the more international sounds of underground rap tend to be associated with groups embedded in the local scene.

I would thus argue that there are two broad camps of artists and artistic philosophies, and while there will always be exceptions that resist such categorisation, it is useful to distinguish between these two camps on the level of terminology. It is possible to form a broad categorisation system for rap, rock and reggaetón musicians in Havana, since there are distinctions between (1) musicians with a localised audience, rooted in a territorialised scene, who embrace 'pure' foreign musical styles and more controversial topics in their lyrics, and (2) musicians who seek a broader 
audience (both in Havana and overseas) and place more emphasis on Cuban musical roots, and whose lyrics are reflective, even somewhat critical, but not confrontational, enabling a more harmonious relationship with state institutions. One of the main arguments for making a distinction between the terms underground and alternative is that they encode quite distinct aesthetic positions - purist/international vs. eclectic/ indigenised - ones that are underpinned by strong, often conflicting views on the ground in Havana.

\section{'The politics is in the drums'}

The politics of musical style in Havana hip hop came into focus in the late 1990s with the efforts of some artists to blend rap with other popular genres in order to create a more commercially appealing and/or artistically satisfying sound. The global success of Orishas served as a high-profile example of the possibilities opened up by fusion. In 1998, two members of Amenaza, a leading group in Havana's underground hip hop scene, left the island for France, where they formed Orishas and blended rap with Cuban musical traditions in their album $A$ lo Cubano, a major worldwide hit released by EMI in 1999. Back in Havana, however, views on Orishas were more mixed. A lo Cubano's success was replicated among general listeners in Cuba, but less so within the hip hop scene.

Havana hip hoppers have been defending their right to adopt international hip hop aesthetics since the early days of the scene. Doble Filo won the Grand Prize at the 1996 Havana hip hop festival with 'Soy de aquí' ('I'm from here'), a defence of Cuban rap as authentically national without having to make surface musical adaptations:

If my rap doesn't have clave it's because people know I'm from here,

I speak Spanish, I'm Cuban, and although I don't mix with son

My roots make me real and raw. ${ }^{6}$

This aesthetic tendency was strengthened from 1998 to 2000, even as Orishas were bursting onto the international stage, when leading US 'conscious' rappers were invited by the New York-based Black August Hip Hop Collective to perform at the annual hip hop festival in Havana. Witnessing first-hand the political and aesthetic lines pursued by groups like Black Star, Common and dead prez, the majority of groups within the Havana scene rejected the path followed by Orishas and pursued a more underground line.

This line has been defended consistently ever since. In their song 'Quisás', Obsesion rap 'I have a rhythm which doesn't wear a guayabera (Cuban shirt)', and go on:

Perhaps it doesn't sound like cha-cha-cha,

But this is the rhythm that identifies me most,

Let it be known from Tokyo to Havana,

This is my way of making Cuban music.

In 'Mirap', El Aldeano defends 'mixing rap with rap', while Explosión Suprema ask on 'Hip hop underground':

What are you singing, mambo, tango, santo?

What are you, dumb, stupid, dense?

Hip hop underground represent! my brother,

Neither mambo nor timba nor reggaetón, my brother. 
The majority of the instrumentals used by the most popular hip hop groups in Havana over the last five years use samples from almost anything except Cuban music, with European classical music a prime source of inspiration. The standard view of US hip hop is that sampling involves a dialogue with black musical traditions of previous generations (Perry 2004, p. 34) and that 'hip hop generates its own history by recycling music' (Perkins 1996, p. 9). The widespread rejection of Cuban music samples and recycling of non-national sources suggest a critique of conventional notions of national culture and identity and a deliberate breaking of the link with local history and tradition. If sampling is a conversation, most of Havana's hip hoppers are calling overseas. Their aesthetic choices articulate their view that Havana is much more than son, rumba and the conga drum, and they oppose hegemonic visions of the nation by challenging its musical symbolism. Their deliberate rejection of local musical materials, which they regard as conventional and frivolous, in favour of seeking out a dark, serious or classic sound, is evidence of an ideology that is both aesthetic and political. Just as Raquel Z. Rivera (2003, p. 186) writes about New York Puerto Rican rappers who embraced their latinidad as 'excising themselves from the hip hop "core"', fusion is perceived by many rappers and hip hop fans in Cuba as pernicious distancing from 'real' hip hop. The underground aesthetic is not simply derivative or musically underdeveloped, then, but more of an active rejection of national stereotypes and an overriding respect for a foreign source. The Buena Vista Social Club project is often invoked as the opposing term, as in underground rap-metal artist Jorge Rafael López's alias Mala Bizta Sochal Klu and his contrasting of his music with that of Compay Segundo, one of the BVSC's stars. ${ }^{7}$

Most of the rap fusions since Orishas appeared have been made by artists who were closely linked to hip hop (X Alfonso) or even central figures in the scene (Ogguere, Telmary, Free Hole Negro, Kumar), but who eventually decided to treat rap as one of a range of musical tools to be used rather than the alpha and omega of music; moving on from identifying solely with hip hop culture, they began to turn their attention to the wider, eclectic, amorphous alternative music scene and a broader range of styles. Free Hole Negro's invention of the moniker 'Free Hop' to describe their music is a good example of the liberal use of rap as one element in the creation of a new style - a form of apostasy from the point of view of hip hop's underground core. For alternative musicians, rap is a tool, a means to a musical end; for the underground, it is one of the four elements of hip hop, a religion in which you either believe or you do not, a way of life and not just a way of making a living. The religious metaphors that abound in hip hop give an insight into why the pick ' $n$ ' mix approach of alternative musicians is regarded with such scepticism.

The widespread resistance to musical localisation has many causes. Many hip hoppers grew up listening primarily to black American music - soul, funk, hip hop - and thus identify more strongly with this music than with Cuban traditions. Key producers like Aldo Rodríguez, Papá Humbertico and Randee Akozta are not interested in timba or other Cuban dance musics. The first attempts at local hip hop production depended on looping instrumental sections from US rap songs; rappers and fans became accustomed to making and hearing international-style hip hop. Even rappers with more fusion tendencies have sometimes been concerned about alienating hip hop audiences (Borges-Triana n.d., p. 7), which grew up on a purist diet of recorded backing tracks and are often unconvinced by the incorporation of live instruments. With the Black August exchanges showcasing US-conscious hip 
hop aesthetics and politics in Havana in the late 1990s, the pull of the international sound was strong.

Also, after EMI released A lo Cubano, fusion became associated with courting foreign record labels (A. Fernández 2000); as Anónimo Consejo note bitterly, 'no one in the record company auditions was interested in groups that did not mix [rap with Cuban music]' (A. Fernández n.d., p. 8). In a scene that was increasingly self-identifying as underground, the perceived link between fusion and commercialism was a significant barrier to musical indigenisation. Cubanised music was associated not only with record labels but also with appealing to the tourists who had been flocking to Havana in increasing numbers since the mid-1990s, hence Mala Bizta Sochal Klu's dismissive allusion to 'the conga drum for the tourists'. Many Havana hip hoppers thus treat the issue of fusion with attitudes ranging from caution to derision, and the core hip hop scene has been a far cry from the merry melting-pot that might be supposed from listening to A lo Cubano (and reading articles on Cuban hip hop).

At the heart of the Havana scene, then, lie contradictions and tensions over aesthetic directions, stemming from the fact that hip hoppers have been pulled between two sources of authenticity - New York and Havana. Leading figures have been aware that too much indigenisation spills over into the suspect realms of music capitalism and tourism, while too little risks alienation from the nationalistic Cuban cultural establishment. They knew the importance of cultural nationalism in order to make a space for hip hop in Cuba, yet saw rap-fusion groups like Orishas and SBS pursue an unabashedly commercial line which ensured that fusion came to equate to selling out in the minds of most hip hoppers. Cubanisation is widely seen among hip hoppers not as a move toward greater sophistication or authenticity but rather as a calculated, even cynical strategy, attempting to invoke stereotypes of national culture in order to open commercial or institutional doors. ${ }^{8}$ Meanwhile, the 'purer' underground hip hop sounds of the US artists brought by the Black August collective were held up as a model of 'real hip hop'. Being true to both New York-style hip hop and Cuban identity was a tough line to tread.

The result is considerable ambivalence, as evident in DJ and promoter Ariel Fernández's (2000) landmark article on Cuban hip hop, in which he both praises and buries fusion, and in an interview that Pablo Herrera, Cuba's leading hip hop producer, gave the same year in which he said 'I only sample Cuban music, nothing else', yet stressed that congas were a no-no: 'The youth that listens to hip-hop wants to listen to something that resembles where the music comes from [...] If you overdo [the percussion], people say, "That's salsa; I've already had enough of that"' (Sokol 2000). The question of percussion - bass and snare or the conga drum - looms large. So what did Herrera sample? Cuban big band, Cuban jazz-fusion and Cuban doowop - not quite the 'traditions' invoked by pro-fusion commentators. It is not as simple as a dash of hip hop, a dollop of son, and voilà - rap cubano. The cultural politics that Herrera had to negotiate were complex, and few other Cuban producers have managed (or even tried) to keep everyone happy in this way, ensuring that the underground/purist and alternative/eclectic aesthetic positions have remained quite separate.

The widespread ambivalence about or resistance to musical localisation may be seen as the latest in a line of (self-)critiques of traditional Afro-Cuban musical practices that goes back to the early 20th century. Then, as today, a tension emerged between traditional music and critical politics. Regino Pedroso, a black poet with 
socialist leanings writing around 1930, objected to the negrista exoticisation of Afro-Cubans and criticised both the appropriation of black culture and the compliance of black Cubans with this appropriation (Gómez García 1998). His verses include 'Black man, black brother / Dampen a while your bongo / [...] Are we not more than rumba, black lust and comparsas?' and 'Black man, black brother / Silence a while your maracas / And learn here / And hear there / And listen over there in Scottsboro, in Scottsboro'.9 Pedroso's lines, like those of Marcelino Arozarena, who in his poem 'Evohé' calls on black Cubans to stop dancing and making merry and pay attention to black suffering, are echoed today by rappers Hermanos de Causa in 'San Cristóbal de La Habana', with its chorus 'San Cristóbal de La Habana is much more than rumba / Much more than cathedral, rum, cigars, and partying', and in the introduction to their rap version of the famous song 'Lágrimas negras', in which the original son version is cut off abruptly after 30 seconds and replaced with a hard hip hop beat - a wordless critique of the capacity of traditional Afro-Cuban music to express the 'black tears' of the new millennium. Providing the background to these examples are the withering remarks about Latin American dance music genres made by many underground rappers in interviews, conversations and songs.

Cuban artists and intellectuals have thus long been aware that the island's cultural traditions need handling with care. One of the great Cuban writers of the 20th century, José Lezama Lima, questioned the idea of surface localism in cultural production as early as 1950, mocking the search for national identity in the arts (Prats Sariol 2008). Within literary circles, Mala Bizta Sochal Klu's dismissal of 'the conga drum for the tourists' would be nothing new: cubanidad or 'local colour' are often associated with self-exoticisation, commercialisation and appeals to the international market, and are regularly dismissed as evidence of shallowness and mediocrity. The underground aesthetic position thus has historical, intellectual and ideological foundations.

\section{Fusion or confusion?}

Clear battle lines were drawn between those who espoused a purist underground aesthetic, strengthened by the Black August exchanges, and those who embraced Orishas-style fusion. Passions ran high over this issue, yet these debates have been played down in written and filmed accounts. Ethnographers and documentary makers from overseas have paid less attention to the fusion groups than to the underground scene. There are practical reasons for this: underground rappers are easier to locate and witness in action, since leading alternative musicians tend not to perform regularly in Havana and are often abroad. Similarly, the close-knit underground scene is a more appealing research object for ethnographers than the alternative groups with their diffuse audience. There is undoubtedly an ideological component to this preference too: foreign activists and social scientists tend to be attracted to the politicised, 'resistant' discourses of the underground rather than the more selfconsciously artistic orientation of fusion groups. The result is that the underground strand of the Cuban hip hop scene has been bolstered by foreign interventions. ${ }^{10}$

In contrast, Cuban commentators have generally brushed over the predominantly underground tendencies of the core hip hop scene and focused on precisely the fusion groups that foreigners tend to ignore. If most overseas analyses are driven 
by the search for political meaning, those closer to home are framed within the discourses of cultural nationalism and oriented much more towards musical meaning. The rejection of musical Cubanisation by most underground artists is not well received by local cultural critics, who tend to view underground styles as amateurish and neglecting the musical in favour of the textual. ${ }^{11} \mathrm{~A}$ certain disdain for underground music is tied up with attachment to the hierarchical professional structure of Cuban popular music making. In other countries, there has been much more of a do-it-yourself attitude to popular music; in Cuba, however, popular music has long been distinguished by the state's rigorous education programmes and the quality control imposed by its professional music agencies. Leading artists are therefore often highly trained musicians. Hence there is a tendency to see adherence to foreign models simply as a lack of ability and professional training rather than an aesthetic or political choice.

In sum, there have been two broad-brush approaches to Cuban hip hop: a social-science view of hip hop as 'social anthropology with rhythm' (Lusane 2004, p. 357), which in fact pays little attention to the rhythm; and a music-critic's view which valorises musical novelty and localisation, and therefore ignores or disparages the majority of hip hop production. Most scholars and critics thus distinguish between what I am categorising as underground and alternative music - even if they do not use those terms in consistent ways - simply by paying considerably more attention to the one or the other. In both cases, however, the aesthetic debates that are so prevalent within urban music circles in Havana are largely elided. It is not simply a case of sins of omission: in some cases, a perfectly defensible personal preference blurs into a distorted view of the field. In a review of the rap compilation Con los Puños Arriba, Danarys Betancourt (n.d., p. 10) stresses the use of Cuban traditional music: 'rhythmic-melodic quotations from our folkloric music, via the inclusion of typical instruments or chants to the orishas of the Afro-Cuban pantheon, the use of rhythmic figures from genres of popular music such as son and from percussion instruments like congas'. In reality, out of 16 tracks on the compilation, only three use a distinctively Cuban beat, with one further track including some Cuban elements in the mix. Far from demonstrating the author's point, this CD illustrates the reality that the majority of Havana rappers, when given a free choice, have tended to opt for an 'international' sound rather than Cuban fusion.

Cuban American scholar Alan West-Durán (2004, p. 8) hears Cuban rap in a similar way to Betancourt: 'The island's Afro-musical traditions are deep-rooted, and hence, Cuban rappers have drawn on Yoruba chants, rumba, mambo, son, and the guaracha to fashion their own and original Cuban rap.' While such examples do of course exist, this depiction elides the majority of rap production in Havana and all the controversy that surrounds the issue of fusion. The result is a Buena Vista-ised view that sounds attractive to Cuban cultural nationalists and foreigners but is markedly distorted. Nevertheless, this view prevails in most written accounts. Margot Olavarria (2008, p. 371), for example, writes that the majority of rap groups use Afro-Cuban rhythms, a possibly appealing but nevertheless inaccurate vision that has taken on a life of its own in print.

A more accurate view of Havana hip hop may be found in the words of Mala Bizta Sochal Klu, who describes his work as 'the dark side of Cuban music ... it's neither Compay [Segundo], with the greatest respect, nor the conga drum for the tourists'. ${ }^{12}$ Anyone who has attended hip hop club nights in Havana over the last few years will recognise the truth of this statement, but this preference for 
underground musical aesthetics provokes scepticism from critics when it is not ignored. The distinguished musicologist Leonardo Acosta (2008, p. 17) only accords value to rap if it is mixed with jazz or Afro-Cuban music; otherwise it is just 'a drum machine with bad poetry'. In an interview with Telmary, rock critic Humberto Manduley López (n.d., p. 6) asks: 'Can her vocal style go beyond rap? [...] is Telmary interested in transcending the possibilities (wide, though not infinite) of hip hop?' The intellectual pressure on purist musical aesthetics is clear.

A number of contributions to Movimiento, Cuba's hip hop magazine, have been made by writers who are not frequent attendees of hip hop club nights, ensuring that such critical agendas, silences and distortions recur with some regularity in print. It is hard to form an accurate view of hip hop aesthetics without attending hip hop performances regularly: compilation CDs can be misleading, since producers may select or create unrepresentative tracks, and even live performances themselves may be deceptive, since showcase events such as the annual hip hop festival and symposium are much more likely to include live musicians and fusion than the regular hip hop peñas. Furthermore, hip hoppers sometimes exaggerate the degree of indigenisation in interviews and even contradict themselves.

Antonio Paneque Brizuela (n.d., p. 18), like many, adopts a cultural nationalist line, arguing that 'for scholars of the subject, Cuban rap is closer to Luis Carbonell or Harry Lewis and to Caribbean music than to North American influences', a view that airbrushes out both the indivisibility of Caribbean and North American in hip hop's origins and the considerable influence of the Black August exchanges in the late 1990s on hip hop aesthetics in Havana. Michael Oramas of underground rap group Junior Clan critiques this blinkered, traditionalist-nationalist view: 'We sometimes feel a great resistance to accepting us, to incorporating us as an integral part of national culture. There are very stereotypical ideas about what the musical roots of this country are' (Plasencia n.d., p. 36). Papá Humbertico, an iconic Havana rapper, recalls in 'Mi historia' ('My story') how, as a 12-year-old, he was 'talking and gesticulating, believing I was from the Bronx', while Alexey Rodríguez of leading group Obsesion raps about the late 1980s in 'Como fue' ('The way it was'):

And there were many like me in Havana,

Dancing and listening just to American music.

Dad bought me a tape player

And my first cassette was by Public Enemy.

Alexis D'Boys, a DJ at the heart of the scene in the early 2000s, was a fan of funk as a child: his father was a merchant sailor who brought foreign, and especially African American, records to Cuba, and hearing Herbie Hancock in 1982 was a seminal moment in his life. For these artists, as for the majority of Havana hip hoppers, African American music was the primary point of reference. Writing about son, guaracha and Luis Carbonell simply obscures this and reveals a political or cultural agenda divorced from local realities.

Paneque Brizuela also argues that the lack of study of Cuban music has been Cuban rappers' Achilles heel. While usefully underlining that local adaptation is not a natural process, as West-Durán implies, but one that requires application, this remark reflects the concern with musical training and superación (selfimprovement) that is characteristic of 'official' Cuban discussions of hip hop and the unusually high value placed on formal musical skills in the administration and analysis of Cuban popular music. Yet it ignores the fact that the majority of rappers 
have as little interest in studying music as they do in conforming to stereotyped notions of national culture. Once again, their points of reference are in US hip hop, in which technological skill, rather than instrumental dexterity or 'musicianship' (as traditionally defined), is central (Perkins 1996, pp. 7-8; Perry 2004, p. 31).

There is a key tension within hip hop about the use of instruments and musicians that Cuban cultural critics fail to grasp. Hank Shocklee, the producer of Public Enemy, lived up to his name on the subject: 'We don't like musicians. We don't respect musicians. [...] We have a better sense of music, a better concept of music, of where it's going, of what it can do. [...] In dealing with rap, you have to be innocent and ignorant of music.' He described his group as 'a musician's nightmare' (Dery 2004, pp. 417-18). While relations between musicians and rappers in Havana have not been quite so antagonistic, the inaccurate and contradictory descriptions of Cuban hip hop as either Buena Vista-ised or desperately in need of a few music lessons mask not only aesthetic-ideological differences between rappers and musicians but also a degree of mutual distrust and misunderstanding. For example, the rapper Kokino (Anónimo Consejo) states that musicians often discriminate against them because of their lack of formal training ('Encuentro entre amigos', Dery n.d., p. 21), while Magia López (a member of Obsesion and currently director of the Cuban Rap Agency) claims that in rap, the text comes first, the beats second, and musicians in last place (Borges-Triana n.d., p. 7). As El Aldeano puts it in 'La papa': 'Musician, me, what instrument do I play? / The reality of a country that's going crazy.' This attitude was mirrored by audiences at rock and rap gigs that I attended, which responded more positively to 'pure' underground sounds than to fusions with Cuban music. Attempts to inject live instruments and local musical styles into rap performances left most hip hop fans cold.

The vision of localised rap presented in many writings about Cuban hip hop thus needs to be qualified in numerous ways: it is only a small part of the story, and a controversial one at that; it is as much a discursive trope as a reality, one regularly repeated for its usefulness rather than its accuracy; and the assumption that underpins it - that indigenised music is superior to non-indigenised - has been contested for decades. The discourse of Cubanisation brushes over the fact that the examples of hip hop fusion that might be produced as evidence have been sources of considerable conflict among hip hoppers; most of their producers have subsequently left (or been ostracised from) the Havana scene.

In most of the Cuban hip hop literature, Cubanisation is either present and praised, or absent and lamented; its value is rarely questioned. Observers have understood underground lyrics to a far greater extent than underground music. Yet Rivera's (2003) argument that hip hop was Latin-Caribbean from the start is highly relevant to Cuba. The conga drum was incorporated and assimilated into hip hop in the 1970s, along with Cuban political influences (Baker 2011a). To echo Rivera, if hip hop is already Cuban, then Cubanised hip hop adds an extra layer that for many fans is redundant. Or to allude to Mala Bizta Sochal Klu, if the conga drum was one of the original building blocks of hip hop, then adding a conga drum today arouses suspicion. 'Localisation' is therefore significantly influenced by state, tourist and music industry imperatives, rather than being the natural, authentic process that is usually portrayed. Rivera reveals that, for all the enthusiasm for indigenisation by record company executives and critics, there has been considerable resistance to Latinisation from within the core of hip hop, with fusion often associated with being soft or fake rather than a badge of authenticity. Latinidad 
may be a route to success in the World Music or fusion markets, but for many hip hop fans it is of peripheral interest. It was the core sound of hip hop - a blend of African, American, Latin and Caribbean influences - that spoke most clearly to young Cuban fans, and their tastes should not be so easily dismissed. The conga drum may thus be seen as an emblem of the debates over the politics of style: for some, the epitome of localisation and authenticity; for others, a symbol of surface exoticism and a bow to tourism and commerce.

Given the huge quantity of international-style hip hop created in Havana over the last 15 years, there is an urgent need to take Cuban underground music seriously as music, rather than ignoring, eliding, inventing or exaggerating. As Jeremy Wallach (2008) argues, scenes based around global music styles attract far more social than musical comment; the music itself is generally regarded as imitating US models and therefore unworthy of attention. But Mala Bizta Sochal Klu's name is as revealing as his comments on the conga drum: it embodies a rejection of the Buena Vista-isation of Cuban culture, and it is this ideological-aesthetic stance that is captured in the sound of underground Havana hip hop. Given the significance of the Buena Vista Social Club for Cuban culture, tourism and national identity over the last dozen years, underground musicians are sending some important messages by explicitly opposing this phenomenon through sound, and it is unfortunate that scholars and critics have paid so little attention to them qua musicians. Wallach's argument that Indonesian punk is a traditionalist, historically rooted musical discourse that provides a stable point of reference for identity finds many echoes in Cuban hip hop. The musical conservatism of Havana hip hop is closely tied to the socio-political conservatism of its lyrical discourses. The musical sounds and the frequent evocation of 'old-school' US hip hop are not signs of imitation or unoriginality but rather the soundtrack to a depiction of a society in decline, in which important values (solidarity, friendship and honesty) are disappearing. In underground hip hop lyrics, the changes going on in Cuban society are almost all for the worse - and it is this conservative worldview, not a failure to evolve, that is encapsulated in underground music.

\section{Underground and commercial}

The principal term to which the term underground serves as antithesis is commercial. This dichotomy is commonly reiterated in discussions within and about Havana's music scenes, both popular and academic (e.g. Fernandes 2006; Saunders 2008; Borges-Triana 2009). ${ }^{13}$ Matters are, however, a little more complicated than they seem.

Looking more closely at Havana's hip hop scene, underground signifies not so much a rejection of the idea of art as commerce as a search for alternative ways of making money. The creation of the Cuban Rap Agency in 2002 split the rap scene in two and concretised a dual economy: a select catalogue of professional groups charged for performing, and the remaining amateur groups were obliged to engage with the underground economy if they wished to make any money from music, since only professional musicians can legally be paid in Cuba. Underground rappers sell home-made CDs - when possible, to foreigners (for a higher price) - and the most successful may receive small cash payments under the table from commercial venues (Baker 2011b). In several documentaries on Cuban hip hop, rappers admit that they live from various grey-economy activities, while Mano Armada claim in their song 
'Lo que hace falta' that 'I get by, I'm pretty handy on the side' (a la zurda soy diestro). Underground hip hop is therefore a contradictory space, encompassing ideologies that overlap with those of the Cuban Revolution (Baker 2011a) but practices that fall outside the control and legal provisions of the state.

Underground is therefore less about non-commercialism than about unofficial ways of making money, since rap has been a significant source of income for many hip hoppers. Highly regarded underground hip hop groups like Explosión Suprema and Los Paisanos were quite open about the importance of generating money from their art when I met them in 2004. ${ }^{14}$ Indeed, many rappers are representative of the broader underground economy, where '[ $t$ ] he nature of Cuba's planned economy itself has inadvertently promoted widespread entrepreneurial values, attitudes, behaviour, and savoir-faire as citizens have had to buy and sell, hustle and "network" in order to improvise solutions to their personal economic problems' (Ritter 2005, pp. 27-8). The hip hop scene of the early 2000s was underground both in the sense of ideologically progressive (and anti-capitalist) and in the contradictory sense that it was a site of small-scale grey-economy activity (microcapitalism); there was an entrepreneurial revolution within the leftist hip hop revolution. Fernandes' (2006) connection of commercial rap with hustling and underground hip hop with hard work misses this crucial (if contradictory) link between rappers' underground ideology and their underground practices.

One of the most intriguing aspects of development of the rap scene in the years 2007-2009 was the emergence of Los Aldeanos as the driving force behind the hip hop underground and, alongside it, the shift of the home base of the scene from noncommercial venues (state-subsidised cultural institutions like La Madriguera, Parque Almendares, and the Casas de la Cultura) to small commercial clubs (Karachi, Atelier, Barbarám). Los Aldeanos' underground fame attracted a large and loyal following, which in turn made them an appealing proposition for small commercial clubs at the very time that their confrontational lyrics were causing them to be viewed askance by cultural institutions. This commercial viability made Los Aldeanos a regular fixture in these venues for a couple of years and - ironically allowed them a degree of control over performance spaces and the opportunity to espouse an underground, politicised lyrical line. The duo thus profited both economically and artistically from the creeping commercialisation of Havana that they so harshly criticised in their lyrics, and the renaissance of underground hip hop in Havana in 2007-2009, a time when hip hop's traditional subsidised venues were increasingly closing their doors, was underpinned by its money-making potential for small commercial venues. Los Aldeanos also promoted an alternative demo $\mathrm{CD}$ market (mercorap) at their regular club night, showing an entrepreneurial spirit that was simultaneously underground and commercial.

The ambiguity around the term underground comes to the surface in Revolution, a documentary about Los Aldeanos. Aldo describes underground as a feeling and a way of life, yet his rap partner El B says that they would not be underground if they had more support from Cuban institutions, stating 'we're underground because we haven't been given any choice'. Melisa Rivière, the duo's international representative, argues that Los Aldeanos' popularity has converted their underground music into commercial. This would seem to concord with Patrick Neate's (2003, p. 12) acerbic view that the difference is really one of scale rather than kind: 'in contemporary hip hop, an underground artist is one who doesn't shift many units'. The fact that the two members of Los Aldeanos and their representative all offered quite different views points to 
greater complexity than is normally allowed, even in scholarly accounts, and suggests that the line between underground and commercial can dissolve at any moment. This proximity rather than polarisation was evident in 2009 and 2010, when Los Aldeanos were courted by Latin music superstars Juanes and Calle 13, and it seems only a matter of time before the duo's underground kudos propels them into the arms of the international music industry. In a sense, as Rivière suggests, Los Aldeanos are already both underground and commercial at the same time, and their trajectory reveals the commercial potential of underground music in an authoritarian context: political risk taking, if carefully managed, can open the door to economic gain.

The difference between underground and commercial is thus far from absolute, since rappers from both camps may perform to paying audiences in commercial clubs. From an underground perspective, making music and selling it is acceptable; it is making music while thinking about selling it that is not - a more subtle distinction. Even this distinction may be something of a mirage: the hip hop economy that I observed in 2004 revolved around selling CDs to foreigners at hip hop gigs, and since most of those foreigners who found their way to these live performances were interested primarily in conscious hip hop, the artists might be seen as satisfying an audience demand. In either case, to equate underground with non-commercial is clearly problematic.

Further blurring of the underground/commercial distinction can be seen in the involvement of international drinks corporations with Cuban urban music. Leading reggaetón groups Cubanito 20.02 and Triángulo Oscuro have been signed up for promotional campaigns by Havana Club rum, with the latter group releasing a song entitled 'Mi Havana Club' on its album Atronco. While this seems to be a world away from underground hip hop, three of Havana's most respected conscious hip hop groups - Obsesion, Doble Filo and Los Aldeanos - signed up to the Havana Club promotional vehicle Havana Cultura. The sponsorship of an annual rap freestyle competition, the Batalla de los Gallos, by Red Bull has tied in many of the most ideologically uncompromising underground rappers with this international brand, one that - in Cuba anyway, where a can costs about a week's state salary - epitomises conspicuous consumption. Perhaps because international marketing is something of a novelty in Cuba, most underground rappers seemed unconcerned by the implications; but it is somewhat ironic that the Red Bull brand has become closely associated with an outspokenly anti-commercial, anti-globalisation music scene. The only real difference from the Havana Club example is that the rappers are doing Red Bull's marketing for free.

\section{Real hip hop}

Attending a hip hop peña in Havana, where underground rappers sing and dance along enthusiastically to recordings of commercial US rap and sell CDs to foreigners, where the figureheads Los Aldeanos are feted as the epitome of underground even as they display more commercial potential than any group since Orishas, it can seem that underground and commercial sit quite happily together. Indeed, the divide between the two does not stem from any inherent contradiction. To draw on Sarah Thornton (1995), commercial is as much an invented category as a reality within the hip hop scene, since the number of rap groups that could be unambiguously tagged with this label is tiny. Its discursive construction allows the supposed underground (in fact, the majority) to feel special, different, counter-cultural. The divide 
was strengthened by the dissemination of a popular origin myth of US hip hop that placed culture and commerce - two aspects of the term underground once tied in a productive dialectic - into conflict.

The underground ideology of hip hop emerged in the USA in the 1990s, often from middle-class hip hoppers, in response to the burgeoning commercial success of the genre. In the preceding decades, hustle and commercialism were a central part of the hip hop story. Nevertheless, old school, underground and non-commercial have become intertwined in the hip hop imaginary, and commercialism is now commonly believed to have been a later imposition on a previously underground culture. This myth has had a major impact in Havana. Rapper Randee Akozta articulates a Cuban underground vision of 'real hip hop': 'The term "real" comes simply, as I understand it, from the hip hop that was made back in the beginning, which was born of protest, and from there I think that a polemic emerged when it divided into underground and commercial [...] and from there came the idea that if you sing commercial shit you're not real because it would be like betraying the origins' ${ }^{15}$ For Anónimo Consejo, their concept ‘Hip hop, Revolución!' shows 'the reality of hip hop, why this culture was born [...], its essence as protest song, as education and social chronicle' (A. Fernández n.d., p. 6). DJ Alexis D’Boys states that 'in underground music, most people have a very positive, educational message, and the music is real because in its beats you can feel the original rhythms of when the culture began on the corners of the poor neighbourhoods of The Bronx and Los Angeles' ('La artillería musical', n.d., p. 16).

The idea of an original, authentic underground hip hop culture which was subsequently corrupted by commercialism is a strong one among hip hoppers and even some academics. Hip hop scholar Marc Perry, who appears as a talking head in the documentary Young Rebels, repeatedly refers to the 'organic' origins of both US and Cuban hip hop, which he contrasts with subsequent commercialisation and institutionalisation, thereby reinforcing the popular myth. In a postmodern context of global cultural flows, it is unclear what would distinguish an 'organic' cultural space from an 'inorganic' one. ${ }^{16}$

The underground ideology and musical aesthetics of the 1990s and 2000s are widely presented as recuperating the original spirit of hip hop in the 1970s. Yet, as many writers have observed, this rests on a distorted view of hip hop history. Hip hop began as music to make people dance, and the kinds of underground beats to which DJ Alexis D'Boys refers are in fact a long way from the funk, disco and Latin-tinged sounds of early hip hop. Rap, meanwhile, developed from the Jamaican practice of 'toasting', which was a means of stoking the party and hyping up the dancers. The early rappers' role was to 'rock the mic', to provide rhythm - the words themselves were often inaudible (Samuels 2004, p. 148) or of little interest to the dancers (see the documentary From Mambo to Hip Hop). David Toop (2000, pp. 120-21) writes that rap in the 1970s Bronx 'wasn't saying much beyond personality commercials'. The idea of rap as protest music emerged a decade later and took a further five years to blossom fully. Furthermore, the notion of a shift from 'pure' protest music to corruption by commerce is equally misleading. The mythical first hip hop party by DJ Kool Herc in 1973 was organised to raise money so that his sister could buy new clothes (Chang 2005, p. 67), and KRS-One describes street entrepreneurship as one of the nine elements of hip hop. Murray Forman (2004, p. 11) underlines that by the late 1970s, 'hip-hop was already part of an entertainment and leisure economy and was, thus, a commercially oriented phenomenon almost from the start'. 
As Davarian Baldwin (2004, p. 161) notes, 'hip hop as a musical form could never follow the traditional association of commodification with cooptation, because the revolution of hip hop was fought out within the circuits of the market'. ${ }^{17}$

Message rap only emerged after hip hop became commercially successful; its most celebrated exponents, Public Enemy, rose to fame after almost a decade of music industry involvement in hip hop, its success dependent on the commercial openings created by earlier groups like Run-DMC. What is perceived by many underground hip hoppers to be the music's essence - its resistive discourses - was thus enabled rather than alienated by commodification (Watkins 2004, p. 571). In Havana, too, conscious hip hop developed out of commercial rap, rather than the other way round. Observers recall early rappers slavishly imitating the lyrics and style of US gangsta rap, and the first group to make a name for itself was the commercially oriented SBS; political rappers like Anónimo Consejo appeared later.

As Jeff Chang (2005, pp. 178-9) reveals, the iconic launch pad of conscious rap, Grandmaster Flash and the Furious Five's 'The Message', was a music-industry creation that was almost forced on a reluctant Flash, who thought that (in Chang's words) 'you went to a party to forget about shit like this'. David Samuels (2004, p. 149) claims that 'the social commentaries of early rappers like Grandmaster Flash and Melle Mel were for the most part transparent attempts to sell records to whites by any means necessary', while Toop (2000, p. 120) describes 'The Message' as 'a highly commercial proposition', revealing the symbiotic rather than oppositional relationship between hip hop's conscious and commercial strands. The idea of 'real hip hop' as anti-commercial message music thus rests on an underground ideology that emerged later and papers over a much less clearly delineated reality.

In practice, then, underground and commercial are deeply entwined, not just in the origins of hip hop in New York in the 1970s, but also in the careers of the conscious rap artists who were invited to Havana by Black August in the late 1990s and who helped incline the local scene more towards the underground. Mos Def and Common are iconic figures for underground hip hoppers, yet they are commercially successful artists who have gone on to appear in Hollywood films and advertise SUVs. In the USA, conscious rap is a commercial category, a niche within the broader hip hop market and a label aimed at consumers of a different kind of lifestyle (Chang 2005 , p. 447). It was precisely rap's commercial success that created the conditions for its niches or subgenres to flourish subsequently, and they did so in ways that overlapped significantly with the mainstream. Behind its underground façade, Rawkus, the iconic 'independent' New York hip hop label, soon began to function in the same way as the majors that frequently distributed its products. The idea that commercial and underground are divided by a fundamental difference in commercial conception rests on a misunderstanding of capitalist culture industries: anything can be niche-marketed, including cultural products that criticise markets and marketing. A division between underground and commercial rap thus serves the music industry that promotes both, and is theoretically problematic in the USA; in Cuba, where the culture industry is structured entirely differently, the problems simply multiply.

\section{'Havana Hip Hop Underground'}

The underground/commercial divide within Havana hip hop was fed by North American ideologies and projections, above all in the late 1990s (Baker 2011a). 
During this period of regular cultural exchange, New York-style, clear-cut categorisation as underground or commercial was transposed repeatedly and directly into the heart of the Havana hip hop scene by North American activists and artists through the Black August exchanges. It was nurtured by resident hip hop leaders like Nehanda Abiodun, a US exile, and Pablo Herrera, who had lived in New York, spoke like a New Yorker, and talked about hip hop like a New Yorker; it was further reinforced by the foreign filmmakers and academics who followed to document the scene, many of whom were steeped in US hip hop. ${ }^{18}$ The blurring of underground and commercial, both in New York in the 1970s and in Havana in the 1990s, was overlooked.

Rap had emerged in the South Bronx at a time of economic hardship; it became 'not only an outlet for social and political discourse, but also an economic opportunity that required little investment other than boldness and a competitive edge' (Lusane 2004, p. 353). Similarly, rap in Havana flourished during the 1990s 'Special Period', the crisis years after the collapse of the Soviet Union and the end of its economic support for Cuba; this was a time marked by heightened entrepreneurial activity and social neglect, a sink or swim environment in which survival was high up the list of priorities. A lot of the underground/commercial discourses that circulated around Havana hip hop ignored the economic necessity and aspirations of many rappers and assumed, somewhat idealistically, that the lack of commercialism in the scene was a matter of ideology and choice. It was easy to view Cuban hip hop as noncommercial in the 1990s because the opportunities for commercial success were limited and rappers were used to getting by on very little; but, as Ariel Fernández - one of the central figures of the Havana scene - told me, 'the view that the world has of Cuban hip hop is a wrong view', since hip hoppers were 'really pro-capitalist people, people who want[ed] to make profit, money from this'. When reggaetón appeared in Havana in the early 2000s, a number of rappers who were supposedly underground grasped the commercial nettle, and others who left the island quickly adapted to commercial necessities when exposed to the outside world. The idea of the underground has been romanticised by foreigners from rich countries, papering over the divergent aims, views and economic circumstances of the rappers who initially fell - by necessity as well as by choice - within that rubric.

Categorisation as underground or commercial is thus, to a significant degree, in the eye of the observer. North Americans often regard the Havana scene as the epitome of non-commercialism, but Cubans from outside the capital see the opposite. As Isnay Rodríguez, a DJ and activist who moved from Santiago de Cuba to work with Obsesion in Havana, told me:

The hip hop movement in Havana reached a peak when lots of people were coming to Havana to nourish themselves on that spirit of hip hop that had been lost for example in the U.S. Many people came and found in the movement in Havana that spirit that had been lost. But I felt (and many people felt) that in Havana there had started the same process that had occurred in the U.S. That unity, that creativity, that community spirit, that commitment to the hip hop movement began to disappear for many reasons: people started to want to be protagonists, to be number one or the best, or they had other interests as artists, like to be signed by a record label, or to have a $C D$ on the market and commercialise their music, because they realised they had a certain appeal to people, and this led to a degradation of the spirituality that the hip hop movement had in Havana.

The Havana scene thus represented underground and commercial at the same time. The international hip hop festival, in particular, became both a celebration of underground hip hop (with the support of the transnational Black August collective) and 
the major commercial moment of the year for local rappers, many of whom sought to profit from the presence of foreign visitors.

The consequences of the myth-making around US and Cuban hip hop have been significant. A simplified, idealised vision of hip hop, with commercial and conscious strains perceived as in opposition, was translated from New York to Havana along with the moral and material support of the Black August collective. To be sure, this vision fell on fertile soil, since the Cuban cultural sphere had long been characterised by what Cuban cultural critic Roberto Zurbano termed, at a talk I attended, a 'fear of money'. This fear should be understood primarily as a negativity surrounding the open pursuit of financial gain, even at a time of great financial need, rather than a literal distaste for cash (it is for this reason that claims that underground is the antithesis of commercial need to be treated with caution). Since it accorded with official Cuban policy on culture, the underground was actually, in one sense, the mainstream in Special Period Havana, a place where the combination of economic crisis and socialism ensured that discussions about money were both pressing and fraught. But what was distinctive about the hip hop scene was the way that, with such close links between the Havana scene and New York activists from 1997 to 2001, foreign ideologies were not simply left to adapt to the Cuban environment but were continually renewed by foreign interventions. Hip hop was subject to the same broad cultural forces as other kinds of Cuban music, but it was also significantly shaped by several years of visits by high-profile North Americans, by American and Americanised hip hop figureheads in Havana, and by the simple fact that most hip hoppers looked to the USA for inspiration and direction. This is why the underground/commercial debate was so strong in hip hop yet absent within timba, for example, and why attitudes to commercial hip hop become more negative as the 1990s progressed, even as Cuban culture in general became more commercialised. The ideas about underground and commercial expressed by Randee Akozta, Anónimo Consejo and Alexis D'Boys all referenced hip hop's origins in the USA; hip hoppers were not simply a subset of Cuban musicians, for the New YorkHavana axis was central to their thinking.

Many of the tensions within the Havana hip hop scene stem from the artificially clear divide between making 'real hip hop' and getting paid, when the US artists who came to Cuba and were idolised by local fans were doing both. Since most groups that wished to pursue more commercial or fusion lines were cold-shouldered and sooner or later abandoned the hip hop scene, and in many cases left the country altogether, this kind of infighting stunted the development of the scene. The majority of Havana artists positioned themselves as underground, and thus as noncommercial, even though many were in fact far from averse to the idea of making money from hip hop, as Ariel Fernández said: they thereby courted exclusion from the mass media and record labels and diminished the opportunity of creating a broad public sphere through hip hop. There was a widespread failure to understand sufficiently that, as Baldwin put it, 'the revolution of hip hop was fought out within the circuits of the market'. Similarly, as George Lipsitz (1994, p. 34) has noted of oppositional cultural practices, 'it is their desire to work through rather than outside of existing structures that defines their utility as a model for contemporary global politics'. If Mos Def and Common have been influential, it is because of (not despite) the capitalist music market. The commercialisation of hip hop is vital to its cultural impact, and its potential political power depends on the degree of alliance that may be forged between its commercial and activist sides (Kitwana 2004). In Havana, these 
two sides ended up at war, driven by the widespread belief that 'real hip hop' was not, and could not be, commercially oriented. The attempt to return to some imagined, utopian, pre-commercial, old-school state ended up cutting hip hop off from the commercial (and dance) roots necessary to sustain it, limiting the capacity of Cuban artists to transcend their local scene and impact on a national audience (though they had more success on the international level, where the Cuban revolutionary brand and dissatisfaction with commercial excess in US hip hop worked in their favour). ${ }^{19}$

I would argue that it is important for scholars and critics to engage with the categories of underground and commercial, which have been central to Cuban hip hop debates, but we would do better to deconstruct the division than to reproduce or reify it. Two of the dominant discourses of Cuban hip hop are actually in contradiction, yet one or other (sometimes both) appears in most writing on the topic, presented as self-evident and never questioned. The cultural nationalist, adoption-adaptation argument sees Cuban hip hop starting out as 'mimetic' of US hip hop (inauthentic) and then growing toward greater localisation (authenticity) as it takes on more Cuban features. The 'commercialisation killed hip hop' argument, however, treats hip hop as an 'organic' essence (authentic) which slowly loses its way under the influence of commerce or institutions (inauthentic). Both positions contain elements of truth and elements of simplification. More important, for my purposes, is to underline that both respond to broader interests: the former reflects the importance of cultural nationalisation for official acceptance in Cuba, and is thus a common discourse among hip hoppers seeking institutional support, but it also appeals to scholars who view localisation as plucky resistance to cultural imperialism; the latter illustrates a widespread, nostalgic, modernist hip hop (and indeed popular music) discourse of authentic roots located in the past, corrupted by The System in the present. To understand urban popular music in Havana, we need to see these discourses for what they are, explore where they come from and examine their impact, rather than treating them as a transparent reflection of reality.

\section{'We're all underground here'}

In Havana, two meanings of the term underground bump up against one another. On the one hand, in both local and global hip hop-speak, underground has come to mean uncompromising, moralistic, non-commercial and often anti-capitalist; on the other, it is also a term that is widely used in relation to the informal economy in Havana, the most capitalist city in 'a nation of hustlers and micro-capitalists' (Carroll 2009). It thus has connotations of inventar ('inventing') and resolver ('resolving') - two very common Cuban expressions - in other words, engaging with the grey morality of the grey economy. Underground means sticking to your line in hip hop - but in everyday life in Havana, it means bending the rules.

Underground hip hop is embedded in a wider underground economy in Havana, to a greater extent than in North America, where underground or conscious hip hop is more of a middle-class phenomenon, and this brings certain tensions between underground ideology and practices. ${ }^{20}$ It is important to recall that hip hop emerged in Havana during the economic upheavals of the Special Period and the partial dollarisation of the economy. It may have been read as underground through the lens of US hip hop and thus attributed ideological characteristics, but 
the circumstances - with parallels to the economic crisis that accompanied the birth of hip hop in New York - meant that the ideologies of resistance to tourism and dollarisation were in tension with the attraction of foreigners and dollars. Written accounts of Cuban hip hop tend to focus on the official underground ideology and ignore its operative faces. I was struck when I started attending hip hop peñas in 2004 that artists would regularly proclaim their underground credentials on stage, disparaging tourism and disdaining commercial motivations in moralistic tones, and would then make a beeline for the nearest foreigner as soon as they finished, $\mathrm{CD}$ in hand, dollars on their mind. Tourists were the focus of critiques on stage and solicitous attention off it. Yet, as I am suggesting here, the operative ideology is not somehow a betrayal of the official, but rather the playing out of a dialectic that can be found both in the complex interplay of moralism and moral ambiguity in contemporary Havana and in the gap between the origins of US hip hop in a time of material scarcity and its 1990s reinvention as anti-materialist 'real hip hop'.

Should I have been so struck by my experiences? Probably not: what I witnessed was, in many ways, 'real hip hop' - a dialectical cultural form in action (Perry 2004). It was the poor fit with the underground ideology of moral rectitude and non-commercialism, one that I had imbibed via numerous written accounts of the Havana scene, which introduced the jarring note. Perhaps I should have thought instead of 'The Message', in which, as Mark Anthony Neal (2004, p. 372) notes, rapper Melle Mel juxtaposes 'diminishing hope and the rampant materialism of the underground economy of the urban landscape', a phrase which could aptly describe Special Period Havana but also, and more importantly, connects (rather than divorcing) materialism and the underground.

Rather than seeing underground as a clear-cut, morally unambiguous category and one pole of a dichotomy, as it is usually presented, we might regard it as containing a powerful dialectic at its heart, a productive tension between ideology and practice. As such, it echoes both hip hop's origins in 1970s New York - where the genre was born out of the revolutionary energy of the Black Panthers and the Young Lords, yet into a time and place of material scarcity - and Cuban society at large during the Special Period. As Esther Whitfield (2008, p. 3) notes, the Special Period was a time when the government called for a heightened sense of morality in a time of crisis, yet also when resolver and inventar became the verbs of the day. The word underground embodies one of the fundamental characteristics of life in contemporary Havana: the tension between morality and necessity, between doing the right thing and doing your own thing.

It is instructive to examine Havana hip hop in the light of Damián Fernández's analysis of Cuban society through the twin lenses of the 'politics of passion' (what should be) and the 'politics of affection' (what is):

The irony is that the Cuban people, though disenchanted, do not abandon totally their aspirations for a new and improved polity and yet continue to act in everyday life in ways detrimental to the normative models they so desire. While seeking in the informal sphere and through the informal practices of the politics of affection satisfaction for immediate needs and wants, they also pursue the utopia implied in the politics of passion. (D. Fernández 2000, p. 41)

The notion of underground is intimately connected to both forms of politics: it encapsulates the strict morality of the politics of passion but also the hustle of the politics of affection. There are thus two underground forces working on hip hoppers, a deep 
and rarely resolved tension that rules out a clear-cut, one-dimensional picture. Both moralistic discourses and hustling practices are part of 'real hip hop', and negotiating this dialectic lies at the heart of hip hop culture. It is only the invention of an underground/commercial divide that converts this productive tension into conflict. But despite efforts to implant a 'cleaned-up' version of hip hop in Havana - just half of the dialectic - the term underground has retained its ambiguous character, encapsulating both anti-commercialism and street entrepreneurship.

The intense debates within the hip hop scene over the underground/commercial question thus reflect not so much a fundamental division between these two terms within hip hop but rather the influence of North American participants and the wider cultural and socio-economic climate of Havana in the 1990s. Debates within the field of literature, too, became dominated by the issues of the market and tourism in the mid- to late 1990s (Whitfield 2008, pp. 80-83); rap's boom time thus coincided with a period when (non-)commercialism was a hot topic in all fields of Cuban culture. In the context of a society that had been thrust rapidly and unexpectedly into the global marketplace, the debates over commercial vs. underground rap (which subsequently transmuted into rap vs. reggaetón) were more than just a sideshow: they encapsulated some of the most pressing social and artistic issues of the time. Cuban rap was in many ways a product of an economic crisis, the Special Period; it is little wonder that economic issues ended up at its heart. Society was seen to be at a crossroads, with commerce as one of the forks, and rappers, like many other residents of the Cuban capital, felt the pressure to make a clear choice about which road to take.

\section{Concluding remarks}

The working definition of underground and alternative proposed above, however imperfect, brings out important distinctions with regard to aesthetic and political positions, social composition, urban geography, and other factors. I believe that academic analyses would do better to focus on these distinctions rather than to follow the popular labelling of separate camps within hip hop as underground and commercial, with its misleading implication that the difference is fundamentally one of economics. To define underground as non-commercial and hidden is unsatisfactory in the case of Havana hip hop: the underground scene has been markedly accessible in recent years, and the move towards greater accessibility - a shift of the scene's hub from the distant suburb of Alamar to venues in the central district of Vedado - was dictated in part by rappers' desire for more contact with CD-purchasing foreigners. To reinforce the idea of underground hip hop as resistant to commerce is to reproduce hip hop's popular myths and ideologies rather than reflect the more complex reality that the two are entwined and have been since the start, and that underground contains a dialectic - morality and hustle.

Why does this matter? A failure to grasp this dialectic is evident in academic discussions of hip hop in Havana; but, more importantly, it has impacted on hip hop itself, which has been hamstrung by bitter divisions over underground vs. commercial and, more recently, hip hop vs. reggaetón. An underground/commercial debate exists in US hip hop, but it was simplified and exaggerated as it was translated into a Cuban context - partly because the issue was more pressing in Havana, due to the Cuban 'fear of money' and the pressures of the Special Period, 
and partly because North American activists were invested in the idea of a purified, non-commercial hip hop scene on the other side of the Florida Straits. However, 'real hip hop' is, and always has been, both underground and commercial, and its greatest impact is achieved through a dialogue, not a battle, with the world of commerce. The construction of 'real hip hop' as non-commercial ultimately weakened this 'revolution within the Revolution'.

Up until 2010, the discursive underground/commercial division has been upheld within the Havana scene, because those rappers who have found commercial success have done so through switching to reggaetón or, as in the case of Orishas, adopting a different musical and lyrical discourse, which meant they could then be accused of having sold out. To finish, somewhat rashly, with a prediction, I suspect that Los Aldeanos will soon hit the commercial big time in the hands of an international producer or record label, while making the same kind of underground music that has brought them national celebrity. Where will that leave local understandings of the terms underground and commercial?

\section{Endnotes}

1. This and all other translations by the author.

2. This article is based on observations made during nine visits to Havana between 2003 and 2010. Those interested in a more extensive study of Havana hip hop may turn to Baker (2011a).

3. This appears in an interview with Emetrece Productions, available at http://www.youtube. $\mathrm{com} /$ watch? $\mathrm{v}=\mathrm{C} 2 \mathrm{OunPSsmy} 4$.

4. There are small spaces for underground music in the Cuban media, such as the radio show 'La Esquina de Rap', but alternative musicians can be heard on mainstream music programs.

5. Max Roach.

6. The clave is a regular rhythmic pattern that underpins many Latin-Caribbean musical genres, such as salsa, son and rumba. Son is a precursor of salsa and a fundament of Cuban popular music.

7. Buena Vista Social Club (1997) was a collaboration between the American guitarist-producer Ry Cooder and a number of (mainly elderly) luminaries of Cuban popular music. It went on to become the most successful world-music album of all time. 1999 saw the release of a follow-up documentary of the same name, directed by Wim Wenders.

8. See Pardue (2008, p. 110) on parallels in Brazilian rap.

9. The poet refers here to the 1931 'Scottsboro incident' $^{\prime}$ in which nine black youths were falsely accused of raping two white women.

10. In the realm of film, the alternative strand has been more evident in fictional offerings like Habana Blues and Música Cubana, which are aimed at a more general audience, than in documentaries.

11. Joaquín Borges-Triana's (2005) review of Free Hole Negro's rap-fusion album is indicative of the general view of underground rap on the part of Cuban critics: 'the CD Superfinos negros shows that there is no reason to associate rap with lesser work, produced by amateur artists, lacking in values in its musical projection and only trying to transmit a message of social criticism'.

12. http://brutalbeatdown.wordpress.com/2007/05/22/ mala-bizta-sochal-klu-vs-buena-vista-social-club/.

13. Although Ferndandes briefly questions these categories (p. 95), she subsequently reaffirms them at length (pp. 103-9). Her reification of the categories of underground and commercial is also let down by the reliance on a single, atypical example of each. Orishas are a unique phenomenon in Cuban rap and live in Europe; to base the categorisation of hip hop in Havana on just one of their songs is highly problematic. Primera Base, meanwhile, showed marked commercial inclinations from the mid-1990s and its key participants all ended up making reggaetón; it is thus far from emblematic of underground hip hop.

14. See, for example, the scene in the film Young Rebels where Los Paisanos talk about the economic importance of rap in their lives (discussed in Baker 2011a).

15. http://rapdiacionlocal.blogspot.com/2007/06/cyberentrevista-randy-acozta.html.

16. For critiques of the theoretically suspect art/commerce dichotomy in academic studies, see Maxwell (2003, pp. 42-3), and Wicke and Shepherd (1993, pp. 35-6).

17. I attended an old-school hip hop event at The Bronx Museum in January 2009 at which a panel of breakdance originators discussed the history of their culture. The single biggest topic of discussion was money: working the streets downtown, 'juicing' (i.e. squeezing cash out of onlookers), 'making a dollar from fifteen cents'. As his concluding remarks, one of the old-school legends said simply: 'this is business'.

18. 'Havana Hip Hop Underground' is one of the more than two dozen documentaries to have 
been made on the local hip hop scene, most of them by foreigners.

19. The rejection of the commercial tag impacted negatively on dance. As rapper Papo Record noted (Petinuad n.d., p. 10), 'hip hop culture is made up of four elements - DJs, rappers, breakdance, and graffiti - and the B-boys or dancers need commercial music to be able to dance. If you censure commercial music you censure breakdance, so you're not looking after your culture.' The role of dance in the Havana hip hop scene has indeed been in decline for many years, resulting in the alienation of a large segment of hip hop's potential audience - a significant consequence of pursuing an uncompromising underground line.

20. On Havana's underground economy, see Henken (2003, 2005).

\section{References}

Acosta, L. 2008. 'Música techno, ruido y medio ambiente', La Gaceta de Cuba, 4, pp. 14-18

Anonymous. n.d. 'La artillería musical', Movimiento, 4, pp. 11-18

Anonymous. n.d. 'Encuentro entre amigos', Movimiento, 2, pp. 18-23

Baker, G. 2011a. Buena Vista in the Club: Rap, Reggaetón, and Revolution in Havana (Durham, NC, Duke University Press)

Baker, G. 2011b. 'Cuba Rebelión: underground music in Havana,' Latin American Music Review, (32/1, pp. 1-38)

Baldwin, D. 2004. 'Black empires, white desires: the spatial politics of identity in the age of hip-hop', in That's the Joint! The Hip-Hop Studies Reader, ed. M. Forman and M.A. Neal (New York, Routledge), pp. 159-76

Betancourt, D. n.d. Review of Con los Puños Arriba, Movimiento, 2, p. 10

Borges-Triana, J. n.d. 'La fabriK: obreros de la construcción y embajadores de la creación', Movimiento, 2, pp. 5-9

Borges-Triana, J. 2005. 'Una fuerza que atrae', Los que soñamos por la oreja: boletín de música cubana alternativa, 10, pp. 59-60

Borges-Triana, J. 2009. Concierto cubano: la vida es un divino guión (Barcelona, Linkgua)

Carrol, R. 2009. 'Cuba: open for Business', Guardian, 14 April

Chang, J. 2005. Can't Stop Won't Stop: A History of the Hip-Hop Generation (New York, Picador)

Dery, M. 2004. 'Public Enemy: confrontation', in That's the Joint! The Hip-Hop Studies Reader, ed. M. Forman and M.A. Neal (New York, Routledge), pp. 407-20

Fernandes, S. 2006. Cuba Represent! Cuban Arts, State Power, and the Making of New Revolutionary Cultures (Durham, NC, Duke University Press)

Fernández, A. n.d. 'Identidades e interiores de ciertos consejos anónimos', Movimiento, 1, pp. 5-10

Fernández, A. 2000. 'Rap cubano: ¿Poesía urbana? O la nueva trova de los noventa', El Caimán Barbudo, $33 / 296$, pp. $4-14$

Fernández, D. 2000. Cuba and the Politics of Passion (Austin, University of Texas Press)

Forman, M. 2004. 'Hip-hop ya don't stop: hip-hop history and historiography', in That's the Joint! The Hip-Hop Studies Reader, ed. M. Forman and M.A. Neal (New York, Routledge), pp. 9-12

Gómez García, C. 1998. 'Cuban social poetry and the struggle against two racisms', in Between Race and Empire: African-Americans and Cubans before the Cuban Revolution, ed. L. Brock and D. Castañeda Fuertes (Philadelphia, Temple University Press), pp. 205-48

Henken, T. 2003. 'Santiago vs. Havana: Cuba's underground economy in comparative perspective', Cuba in Transition (Association for the Study of the Cuban Economy), pp. 348-53

Henken, T. 2005. 'Entrepreneurship, informality, and the second economy: Cuba's underground economy in comparative perspective', Cuba in Transition (Association for the Study of the Cuban Economy), pp. 360-75

Kitwana, B. 2004. 'The challenge of rap music from cultural movement to political power', in That's the Joint! The Hip-Hop Studies Reader, ed. M. Forman and M.A. Neal (New York, Routledge), pp. 341-50

Lipsitz, G. 1994. Dangerous Crossroads: Popular Music, Postmodernism and the Poetics of Place (London, Verso)

Lusane, C. 2004. 'Rap, race, and politics', in That's the Joint! The Hip-Hop Studies Reader, ed. M. Forman and M.A. Neal (New York, Routledge), pp. 351-62

Manduley López, H. n.d. 'Telmary: con tanto de amor como de caos', Movimiento, 4, pp. 5-6

Maxwell, I. 2003. Phat Beats, Dope Rhymes: Hip Hop Down Under Coming Upper (Middletown, Wesleyan University Press)

Neal, M.A. 2004. 'Postindustrial soul: black popular music at the crossroads', in That's the Joint! The Hip-Hop Studies Reader, ed. M. Forman and M.A. Neal (New York, Routledge), pp. 363-87

Neate, P. 2003. Where You're at: Notes from the Frontline of a Hip Hop Planet (London, Bloomsbury)

Nooshin, L. 2005. 'Underground, overground: rock music and youth discourses in Iran', Iranian Studies, 38/3, pp. 463-94

Olavarria, M. 2008. 'Rap and revolution: hip-hop comes to Cuba', in A Contemporary Cuba Reader: Reinventing the Revolution, ed. P. Brenner et al. (Lanham, Rowman and Littlefield), pp. 369-72

Paneque Brizuela, A. n.d. '¿Está ocupando el rap su lugar en la vida?', Movimiento, 3, pp. 16-19

Pardue, D. 2008. Ideologies of Marginality in Brazilian Hip Hop (New York, Palgrave Macmillan) 
Perkins, W.E. 1996. 'The rap attack: an introduction', in Droppin' Science: Critical Essays on Rap Music and Hip Hop Culture, ed. W.E. Perkins (Philadelphia, Temple University Press), pp. 1-45

Perry, I. 2004. Prophets of the Hood: Politics and Poetics in Hip Hop (Durham, NC, Duke University Press)

Petinuad, J. n.d. 'Papo Record: yo no critico al que es comercial', Movimiento, 4, pp. 8-10

Plasencia, A. n.d. 'The Junior Clan: a la carga otra vez', Movimiento, 3, pp. 35-7

Prats Sariol, J. 2008. 'Cuba: literatura sin viejos conflictos', unpublished paper.

Ritter, A. 2005. 'Cuba's underground economy'. http://www2.carleton.ca/economics/ccms/wp-content/ ccms-files/cep04-12.pdf.

Rivera, R.Z. 2003. New York Ricans from the Hip Hop Zone (New York, Palgrave Macmillan)

Samuels, D. 2004. 'The rap on rap: the "black music" that isn't either', in That's the Joint! The Hip-Hop Studies Reader, ed. M. Forman and M.A. Neal (New York, Routledge), pp. 147-53

Saunders, T. 2008. 'The Cuban remix: rethinking culture and political participation in contemporary Cuba', PhD thesis (Ann Arbor, University of Michigan)

Sokol, B. 2000. 'Hip hop and socialism: in Cuba the revolution will be rhymed', Miami New Times, 20 July

Szemere, A. 2001. Up from the Underground: The Culture of Rock Music in Postsocialist Hungary (University Park, Penn State University Press)

Thornton, S. 1995. Club Cultures: Music, Media and Subcultural Capital (Cambridge, Polity Press)

Toop D. 2000. Rap Attack 3: African Rap to Global Hip Hop (London, Serpent's Tail)

Wallach, J. 2008. 'Living the punk lifestyle in Jakarta', Ethnomusicology, 52/1, pp. 98-116

Watkins, S.C. 2004. 'Black youth and the ironies of capitalism', in That's the Joint! The Hip-Hop Studies Reader, ed. M. Forman and M.A. Neal (New York, Routledge), pp. 557-78

West-Durán, A. 2004. 'Rap's diasporic dialogues: Cuba's redefinition of blackness', Journal of Popular Music Studies, $16 / 1$, pp. 4-39

Whitfield, E. 2008. Cuban Currency: The Dollar and 'Special Period' Fiction (Minneapolis, University of Minnesota Press)

Wicke, P., and J. Shepherd. 1993. "The cabaret is dead": rock culture as state enterprise - the political organization of rock in East Germany', in Rock and Popular Music: Politics, Policies, Institutions, ed. T. Bennett et al. (London, Routledge), pp. 25-36 